Postgraduate Bosowa University Publishing (PBUP)
Indonesian Journal of Business and Management
e-ISSN: $2460-3767 \quad p$-ISSN: $2656-6885$

\title{
AKUNTABILITAS, TRANSPARANSI DAN PARTISIPASI PENYUSUNAN ANGGARAN TERHADAP KINERJA ANGGARAN PADA PEMERINTAH DAERAH LUWU TIMUR
}

\author{
Accountability, Transparency and Participation in Budget Preperation on the Budget Performance of \\ the Government of East Luwu Region
}

\author{
Jumarti Achmad ${ }^{1}$, Haeruddin Saleh², Cahyono \\ ${ }^{1}$ Badan Pengelolaan Keuangan Daerah Kabupaten Luwu \\ ${ }^{2}$ Program Studi Magister Manajemen Pascasarjana Universitas Bosowa \\ Email: aty.alamsyah@gmail.com
}

Diterima: 01 Maret 2020/Disetujui: 05 Juni 2020

\begin{abstract}
ABSTRAK
Pentingnya fungsi dan pengukuran kinerja maka pemerintah membuat sistem pengukuran kinerja yang disebut dengan Sistem Akuntabilitas Kinerja Instansi Pemerintah (SAKIP). Pelaporan akuntabilitas kinerja instansi pemerintah dimaksudkan untuk mengetahui kemampuan pemerintah dalam pencapaian visi, misi, dan tujuan organisasi, melalui pengukuran kinerja anggaran. Penelitian ini bertujuan untuk mengetahui dan menganalisis pengaruh akuntanbilitas, transparansi dan partisipasi penyusunan anggaran terhadap kinerja anggaran pada Pemerintah Daerah Kabupaten Luwu Timur. Penelitian ini menggunakan pendekatan kuantitatif, teknik pengumpulan data melalui penyebaran kuesioner. Sedangkan teknik analisis data menggunakan analisis deskriptif, uji kualitas data (uji validitas dan reliabilitas), uji asumsi klasik, analisis regresi berganda, uji hipotesis serta koefisien determinasi. Hasil penelitian menemukan bahwa akuntabilitas berpengaruh positif dan signifikan terhadap kinerja anggaran pada Kantor Pemerintah Daerah Kabupaten Luwu Timur. Transparansi berpengaruh positif dan signifikan terhadap kinerja anggaran pada Kantor Pemerintah Daerah Kabupaten Luwu Timur. Partisipasi penyusunan anggaran berpengaruh positif dan signifikan terhadap kinerja anggaran pada Kantor Pemerintah Daerah Kabupaten Luwu Timur. Dari hasil pengujian regresi maka diketahui bahwa variabel yang dominan berpengaruh terhadap kinerja anggaran pada Kantor Pemerintah Daerah Kabupaten Luwu Timur adalah partisipasi penyusunan anggaran.
\end{abstract}

Kata Kunci: Akuntabilitas, Transparansi, Partisipasi Penyusunan Anggaran, Kinerja Anggaran.

\begin{abstract}
Due to the importance of functions and performance measurements, the government made a performance measurement system called the Accountability System for Government Institutions' Performance (SAKIP). Performance accountability report of government institutions is intended to determine the ability of the government in achieving the vision, mission, and goals of the organization, through measurement of budget performance. This study aims to determine and analyze the effect of accountability, transparency and participation in budgeting on budget performance in the Regional Government of East Luwu Regency. This research uses a quantitative approach with data collection techniques through questionnaires. Meanwhile, the data analysis technique uses descriptive analysis, data quality tests (validity and reliability tests), classic assumption tests, multiple regression analysis, hypothesis testing and coefficient of determination. The results of the study found that accountability had a positive and significant effect on budget performance. Transparency has a positive and significant effect on budget performance in the Government Office of East Luwu Regency. Participation in budgeting has a positive and significant effect on budget performance at the Regional Government Office of East Luwu Regency. From the results of regression test, it is known that the variable dominantly influencing budget performance at the Regional Government Office of East Luwu Regency is budgeting participation.
\end{abstract}

Keywords: Accountability, Transparency, Participation in Budgetin, Budget Performance 


\section{PENDAHULUAN}

UU. No 23 tahun 2014 mengenai pemerintah daerah yang menyatakan bahwa efisiensi dan efektivitas penyelenggaraan pemerintahan daerah perlu ditingkatkan dengan lebih memperhatikan aspek hubungan antara pemerintah pusat dengan pemerintah daerah dan antar daerah, potensi dan keanekaragaman daerah serta peluang dan tantangan persaingan global dalam kesatuan sistem penyelenggaraan pemerintahan negara. Keberhasilan penyelenggaraan pemerintahan daerah sangat ditentukan oleh kinerja organisasi sektor publik, hal ini didukung oleh pendapat Mahmudi (2016) bahwa kinerja organisasi sektor publik harus terus ditingkatkan secara berkelanjutan dan berkesinambungan, karena sektor publik merupakan sektor yang dinamis maka manajemen sektor publik harus selalu menyesuaikan dengan dinamika perkembangan lingkup organisasi, sosial, budaya, politik dan teknologi. Kinerja (performance) merupakan bagian yang penting khusus di sektor pubik, alasannya karena kinerja merupakan gambaran mengenai tingkat pencapaian pelaksanaan tugas dalam suatu organisasi guna mewujudkan sasaran, tujuan, misi dan visi organisasi tersebut.

Kinerja dalam suatu organisasi dapat dilihat dari tingkatan sejauh mana organisasi dapat mencapai tujuan yang didasari pada tujuan yang didapatkan pada tujuan yang sudah ditetapkan sebelumnya. Tujuan yang dimaksud mengacu pada luaran seperti yang ditegaskan oleh Moeheriono (2012) bahwa kinerja menekankan pada apa yang dihasilkan (output) dari fungsi-fungsi suatu pekerjaan atau manfaat yang keluar (outcome). Pentingnya kinerja dalam suatu organisasi pemerintahan maka perlu dilakukan pengukuran kinerja, dimana sistem pengukuran kinerja yang berorientasi publik dapat membantu kinerja pemerintah, pengalaman sumber daya dan membantu keputusan dan mewujudkan pertanggungjawaban publik dan memperbaiki komunikasi dan kelembagaan.

Pentingnya fungsi dan pengukuran kinerja maka pemerintah membuat sistem pengukuran kinerja dengan nama Sistem Akuntabilitas Kinerja Instansi Pemerintah (SAKIP). Dalam PP. No. 7 tahun 1999 bahwa dalam rangka meningkatkan pelaksanaan pemerintah yang lebih berdaya guna, bersih dan bertanggungjawab dipandang perlu adanya pelaporan kinerja instansi pemerintah. Pelaporan akuntabilitas kinerja instansi pemerintah dimaksudkan untuk mengetahui kemampuan pemerintah dalam pencapaian visi, misi, dan tujuan organisasi, sehingga pengukuran kinerja yang difokuskan dalam penelitian ini adalah kinerja anggaran.

Kinerja anggaran yang lebih dikenal dengan anggaran berbasis kinerja merupakan suatu sistem anggaran yang mengutamakan upaya dalam pencapaian hasil kerja atau output dan perencana alokasi biaya atau input yang ditetapkan. Sehingga Anggarini dan Puranto (2010) yang mengemukakan bahwa sistem penganggaran kinerja merupakan suatu sistem penyusunan anggaran yang menekankan pada hasil dan pengendalian belanja.
Sistem ini terutama berusaha untuk mengaitkan langsung antara keluaran (output) dengan hasil (outcomes) yang disertai dengan penekanan terhadap efektivitas dan efisiensi anggaran yang dialokasikan.

Perencanaan kinerja anggaran atau anggaran berbasis kinerja mendesain program perencanaan kinerja yang terdiri dari program dan kegiatan yang akan dilaksanakan serta indikator kinerja yang ingin dicapai dalam suatu entitas penggunaan anggaran (budget entity), oleh karena itulah terdapat sejumlah faktor yang dapat mempengaruhi kinerja anggaran diantaranya akuntabilitas, transparansi dan partisipasi penyusunan anggaran (Halim et al., 2019).

Pemerintah Daerah Kabupaten Luwu Timur yang aktivitasnya memberikan pelayanan kepada publik, di mana visinya adalah Kabupaten Luwu Timur Terkemuka 2021. Salah satu misinya adalah mendorong reformasi birokrasi untuk tata kelola pemerintahan yang baik dengan peningkatan pelayanan publik. Berdasarkan hasil penilaian tingkat akuntabilitas kinerja atau pertanggungjawaban atas hasil yang menunjukkan bahwa tingkat efektivitas dan efisiensi penggunaan anggaran masih rendah jika dibandingkan dengan capaian kinerja. Hal ini dilihat bahwa tingkat akuntabilitas kinerja Pemerintah Daerah Kabupaten Luwu Timur selama 4 tahun terakhir masih rendah dengan penilaian $\mathrm{C}$ atau agak kurang khususnya untuk tahun 2015 dan 2016, sedangkan penggunaan anggaran pada tahun 2017 dan 2018 dengan penilaian CC atau cukup baik, namun hal ini tidak seimbang dengan capaian kinerja yang dicapai oleh Pemerintah Daerah Kabupaten Luwu Timur.

Berdasarkan data tingkat kinerja Pemerintah Daerah Kabupaten Luwu Timur masih rendah, sedangkan realisasi Anggaran Pendapatan dan Belanja Daerah cukup baik mencapai 100 persen, sehingga peneliti melakukan kajian kinerja anggaran dalam penelitian ini dipengaruhi akuntabilitas, transparansi dan partisipasi anggaran. Akuntabilitas mengacu pada teori yang dikemukakan oleh Tanjung (2014) bahwa akuntabilitas merupakan usaha untuk mempertanggungjawabkan pengelolaan sumber daya serta pelaksanaan kegiatan suatu entitas pelaporan anggaran yang dipercayakan kepada entitas pelaporan dalam mencapai tujuan yang telah ditetapkan secara periodik. Transparansi mengacu pada teori yang dikemukakan oleh Mardiasmo (2010) bahwa transparansi berarti keterbukaan openness pemerintah dalam memberikan informasi yang terkait dengan aktivitas pengelolaan sumber daya public kepada pihak-pihak yang membutuhkan informasi dan partisipasi anggaran yang mengacu pada teori Brownell (1982) bahwa partisipasi anggaran menunjukkan seberapa luasnya individu terlibat dan memiliki pengaruh dalam penentuan anggaran.

\section{METODE}

\subsection{Jenis Penelitian}

Jenis penelitian yang digunakan adalah kuantitatif, hal ini disebabkan karena penelitian ini disajikan dengan angka-angka, sebagaimana dikemukakan oleh Arikunto 
(2012) bahwa penelitian kuantitatif adalah pendekatan penelitian yang banyak dituntut menggunakan angka, mulai dari pengumpulan data, penafsiran terhadap data tersebut, serta penampilan hasilnya. Jenis penelitian dengan pendekatan asosiatif yakni penelitian yang bertujuan untuk mengetahui pengaruh atau hubungan antara dua variabel atau lebih (Sugiyono, 2016). Oleh karena itu dalam penelitian ini peneliti ingin mengkaji pengaruh akuntabilitas, transparansi, dan partisipasi penyusunan anggaran terhadap kinerja anggaran pada Pemerintah Daerah Kabupaten Luwu Timur melalui penyebaran kuesioner kepada responden yang menjadi sampel dalam penelitian ini.

\subsection{Lokasi Penelitian}

Penelitian ini dilakukan pada Kantor Pemerintah Daerah Kabupaten Luwu Timur. Alasan mendasar yang dijadikan pertimbangan dalam pemilihan obyek penelitian ini adalah juga mengangkat permasalahan yang sangat relevan dengan obyek penelitian.

\subsection{Populasi dan Sampel}

Populasi atau universe adalah jumlah keseluruhan dari satuan-satuan atau individu-individu yang karakteristiknya hendak diteliti. Populasi dalam penelitian ini adalah SKPD di Kabupaten Luwu Timur yang berjumlah sebanyak 39 SKPD, dengan jumlah pegawai pemeriksa dari masing-masing SKPD terdiri dari Pengguna Anggaran 39 orang, Kasubag. Perencanaan 39 orang, Kasubag. Keuangan 39 orang dan PPK SKPD 39 orang, sehingga berjumlah sebanyak 156 responden.

Sampel adalah sebagian dari populasi yang karakteristiknya hendak diteliti, dimana jumlah sampel ditentukan sebanyak 156 orang (4 orang x 39 SKPD yang ada di Kabupaten Luwu Timur). Sedangkan untuk menentukan jumlah sampel maka digunakan rumus slovin sehingga diperoleh jumlah sampel sebanyak 112 orang. Sedangkan penentuan sampel menggunakan metode purposive sampling yakni Pegawai yang memiliki masa kerja di atas dari 3 tahun serta terlibat langsung dalam penyusunan anggaran.

\subsection{Variabel Penelitian}

Variabel independen adalah variabel yang tidak dipengaruhi oleh variabel-variabel lain melainkan variabel yang mempengaruhi variabel terikat. Variabel Independen dalam penelitian ini adalah Akuntabilitas $\left(\mathrm{X}_{1}\right)$, transparansi $\left(\mathrm{X}_{2}\right)$ dan partisipasi penyusunan anggaran $\left(\mathrm{X}_{3}\right)$, sedangkan variabel dependen adalah variabel yang dipengaruhi oleh variabel independen yaitu kinerja anggaran dianggap sebagai variabel terikat (Y).

\subsection{Teknik Pengumpulan Data}

Teknik pengumpulan data melalui penyebaran kuesioner yakni daftar pertanyaan yang diberikan peneliti pada responden untuk diberikan jawaban. Kuesioner terdiri dari pertanyaan terbuka, yaitu pertanyaan yang berkaitan dengan identitas responden serta pertanyaan tertutup yaitu pertanyaan yang meminta responden untuk memilih salah satu jawaban yang telah tersedia.
Pertanyaan dibuat dalam bentuk angket dengan menggunakan skala Likert 1-5 yang masing-masing mewakili pendapat dari responden. Pada penelitian ini, responden diharuskan memilih salah satu dari kelima alternatif jawaban yang tersedia. Nilai yang diperoleh akan dijumlahkan dan jumlah tersebut menjadi nilai total.

\subsection{Jenis dan Sumber Data}

Jenis data yang digunakan dalam penelitian ini adalah a. Data kualitatif, yaitu data yang tidak dapat dihitung atau data yang bukan dalam bentuk angka-angka seperti profil Pemerintah Daerah Kabupaten Luwu, struktur organisasi serta visi dan misi. b. Data kuantitatif yaitu data yang dapat dihitung atau data yang berupa angka-angka yang masih perlu dianalisis serta data lainnya yang menunjang penelitian ini.

Sumber data dengan menggunakan: a. Data primer yang dihasilkan dalam penelitian ini adalah merupakan hasil dari tanggapan responden melalui penyebaran kuesioner terhadap variabel-variabel penelitian yang akan diuji dengan menggunakan sistem komputerisasi melalui program SPSS release 24 sehingga diperoleh hasil output SPSS, b. Data sekunder yaitu data penelitian yang diperoleh melalui perantara. Data sekunder diperoleh dari literatur-literatur, buku-buku, jurnal-jurnal, dan sumber lainnya, yang berkaitan dengan topik yang diangkat pada penelitian ini, yang dibutuhkan untuk mendukung variabel-variabel yang digunakan dalam penelitian ini.

\subsection{Analisis Data}

Metode yang digunakan untuk menganalisis pokok permasalahan untuk mencari pemecahan atas masalah yang dikemukakan sebelumnya adalah sebagai berikut.

1. Analisis Deskriptif,

Analisis deskriptif adalah suatu analisis yang menggambarkan persepsi responden mengenai akuntabilitas, transparansi dan partisipasi penyusunan anggaran terhadap kinerja anggaran pada Pemerintah Daerah Kabupaten Luwu Timur

2. Uji Kualitas Data

\section{a. Uji Reliabilitas}

Instrumen yang dikembangkan dalam daftar pertanyaan, dianggap reliabel apabila mempunyai tingkat konsistensi hasil yang dicapai. Untuk mengikuti tingkat konsistensi hasil yang dicapai oleh sebuah alat ukur, maka dilakukan uji reliabilitas. Pengujian reliabilitas dalam penelitian ini dilakukan dengan menggunakan teknik belah dua.

\section{b. Uji Validitas}

Instrumen penelitian yang dianggap valid adalah suatu instrumen yang benar-benar mampu mengukur variabelnya. Untuk mengetahui apakah instrumen tersebut valid maka dilakukan uji validitas dengan menggunakan analisis kesalihan butir, dengan teknik korelasi produk moment (momen takar). 
3. Uji asumsi klasik

Penggunaan analisis regresi dalam statistik harus bebas dari asumsi-asumsi klasik seperti normalitas data, heterokedasitas, dan uji multikoli-neritas.

4. Analisis regresi linier berganda adalah suatu analisis yang digunakan untuk mengetahui ada tidaknya pengaruh antara variabel bebas dan variabel terikat menurut Suliyanto (2018) yaitu:

$$
\mathrm{Y}=\beta_{0}+\beta_{1} \mathrm{X}_{1}+\beta_{2} \mathrm{X}_{2}+\beta_{3} \mathrm{X}_{3}+\mathrm{e}
$$

5. Uji Hipotesis

a) Uji Signifikansi Simultan (Uji F)

Dalam penelitian ini, uji $\mathrm{F}$ digunakan untuk mengetahui tingkat siginifikansi pengaruh variabel-variabel independen secara bersamasama (simultan) terhadap variabel dependen Ghozali, (2016).

b) Uji Signifikansi Pengaruh Parsial (Uji t)

Uji t digunakan untuk menguji signifikansi hubungan antara variabel $\mathrm{X}$ dan $\mathrm{Y}$, apakah variabel $\mathrm{X}_{1}, \mathrm{X}_{2}, \mathrm{X}_{3}$, (akuntabilitas, transparansi dan partisipasi penyusunan anggaran) benarbenar berpengaruh signifikan terhadap variabel kinerja anggaran Y (Ghozali, (2016).

c) Koefisien Determinasi $\left(\mathrm{R}^{2}\right)$

Koefisien determinasi $\left(\mathrm{R}^{2}\right)$ dimaksudkan untuk mengetahui tingkat ketepatan paling baik dalam analisa regresi dimana hal yang ditunjukkan oleh besarnya koefisien determinasi $\left(R^{2}\right)$ antara 0 (nol) dan I (satu). Koefsien determinasi $\left(\mathrm{R}^{2}\right)$ nol variabel independen sama sekali tidak berpengaruh terhadap variabel dependen. Apabila koefisien determinasi semakin mendekati satu, maka dapat dikatakan bahwa variabel independen berpengaruh terhadap variabel dependen, Selain itu koefisien determinasi $\left(\mathrm{R}^{2}\right)$ dipergunakan untuk mengetahui prosentase perubahan variabel tidak bebas $(\mathrm{Y})$ yang disebabkan oleh variabel bebas (X).

\section{HASIL DAN PEMBAHASAN}

Secara konseptual, akuntabilitas mengacu pada adanya kewajiban bagi pihak pemegang amanah (agent) untuk memberikan pertanggungjawaban, menyajikan, melaporkan dan mengungkapkan segala aktivitas dan kegiatan yang menjadi tanggungjawabnya kepada pihak pemberi amanah yang menilai hasil dan kewenangan untuk meminta pertanggungjawaban tersebut Anggarini dan Puranto (2010). Akuntabilitas berpedoman terhadap kinerja anggaran, hal ini didasari dari penelitian yang dilakukan oleh Setyaningrum (2017) yang menemukan bahwa akuntabilitas berpengaruh positif dan signifikan terhadap kinerja anggaran. Selain itu Purnomo dan Putri (2018) bahwa akuntabilitas berpengaruh signifikan terhadap kinerja anggaran, sedangkan Arifani (2018) yang menemukan bahwa akuntabilitas tidak berpengaruh terhadap kinerja anggaran. Penelitian ini ditemukan ada riset gap karena terdapat perbedaan dari hasil temuan yang dilakukan oleh peneliti sebelumnya.
Transparansi merupakan salah satu prinsip dalam good corporate governance, dimana transparansi dapat dimaknai sebagai tersedianya informasi yang cukup, akurat dan tepat waktu tentang kebijakan publik dan proses pembentukan. Transparansi berpengaruh terhadap kinerja anggaran. Hal ini didasari dari penelitian yang dilakukan oleh Setiyaningrum (2017) menemukan bahwa transparansi berpengaruh positif dan signifikan terhadap kinerja anggaran, sedangkan Adiwirya dan Sudana (2015) bahwa transparansi berpengaruh positif pada anggaran berbasis kinerja, selain itu Purnomo dan Putri (2018) menemukan bahwa transparansi berpengaruh signifikan terhadap kinerja. Berbeda dengan penelitian yang dilakukan oleh Supriandi (2017) yang menemukan bahwa transparansi memiliki hubungan negatif dan tidak signifikan terhadap kinerja organisasi nirlaba. Dengan demikian dalam penelitian ini ditemukan ada riset gap karena dalam penelitian sebelumnya tidak konsisten.

Faktor lainnya yang mempengaruhi kinerja anggaran yaitu partisipasi penyusunan anggaran. Dimana partisipasi penyusunan anggaran menciptakan kesempatan pada bawahan untuk terlibat dan mempengaruhi proses penyusunan anggaran. Faktor yang mempengaruhi kinerja anggaran yang salah satunya adalah partisipasi penyusunan anggaran, hal ini didasari dari penelitian yang dilakukan oleh Anwar dan Sumiati (2014), hal ini menunjukkan bahwa partisipasi penyusunan anggaran berpengaruh signifikan terhadap kinerja aparat pemerintah daerah, penelitian Handayani (2011) menemukan bahwa partisipasi penyusunan anggaran berpengaruh terhadap kinerja anggaran. Hasil penelitian yang dilakukan oleh Ashari (2013) menemukan bahwa partisipasi penyusunan anggaran tidak berpengaruh terhadap kinerja manajerial pada sejumlah kantor SKPD. Menurut Nafarin (201) anggaran adalah suatu rencana tertulis mengenai kegiatan suatu organisasi yang dinyatakan secara kualitatif dan umumnya dinyatakan dalam satuan uang atau dalam jangka waktu tertentu

\section{Analisis Multiplier Regression}

Untuk mengetahui pengaruh antara variabel bebas terhadap variabel terikat maka dilakukan analisis persamaan regresi dengan menggunakan sistem komputerisasi program SPSS release 24 atas variabel akuntabilitas, transparansi dan partisipasi penyusunan anggaran terhadap kinerja anggaran pada kantor Pemerintah Daerah Kabupaten Luwu Timur yang dapat dilihat melalui Tabel 1 berikut ini.

Tabel 1. Hasil Olahan Data Persamaan Regresi atas Akuntabilitas, Transparansi, dan Partisipasi Penyusunan Anggaran terhadap Kinerja Anggaran

\begin{tabular}{|c|c|c|c|c|c|c|}
\hline & \multirow[t]{2}{*}{ Model } & \multicolumn{2}{|c|}{$\begin{array}{c}\text { Unstandardized } \\
\text { Coefficients }\end{array}$} & \multirow{2}{*}{$\begin{array}{c}\begin{array}{c}\text { Standardized } \\
\text { Coefficients }\end{array} \\
\text { Beta }\end{array}$} & \multirow[b]{2}{*}{$\mathrm{t}$} & \multirow{2}{*}{ Sig. } \\
\hline & & $\mathrm{B}$ & $\begin{array}{l}\text { Std. } \\
\text { Error }\end{array}$ & & & \\
\hline \multirow[t]{6}{*}{1} & (Constant) & .659 & .359 & & 1.839 & .069 \\
\hline & Akuntabilitas & .181 & .087 & .168 & 2.080 & .040 \\
\hline & Transparansi & .265 & .067 & .312 & 3.941 & .000 \\
\hline & $\begin{array}{l}\text { Partisipasi P. } \\
\text { Anggaran }\end{array}$ & .420 & .075 & .422 & 5.589 & .000 \\
\hline & \multicolumn{6}{|c|}{$\mathrm{R}=0,712$} \\
\hline & \multicolumn{6}{|c|}{$\mathrm{R}^{2}=0,507$} \\
\hline
\end{tabular}


Berdasarkan Tabel 1 tersebut di atas yakni hasil olahan data SPSS versi 24 maka dapat disajikan persamaan regresi berganda yaitu sebagai berikut :

$\mathrm{Y}=0,659+0,181 \mathrm{X}_{1}+0,265 \mathrm{X}_{2}+0,420 \mathrm{X}_{3}$

Untuk lebih jelasnya hasil persamaan regresi dapat diinterprestasikan sebagai berikut :

1. Koefisien konstanta $\left(b_{o}\right)$ sebesar 0,659 yang artinya dengan adanya akuntabilitas, transparansi dan partisipasi penyusunan anggaran maka kinerja anggaran pada Pemerintah Daerah Kabupaten Luwu Timur sebesar 0,659.

2. Koefisien regresi $\left(b_{1}\right)$ sebesar 0,181 yang diartikan bahwa akuntabilitas berpengaruh positif terhadap kinerja anggaran, yang artinya bahwa dengan adanya kenaikan akuntabilitas maka kinerja anggaran akan meningkat sebesar $0,181 \%$.

3. Koefisien regresi $\left(b_{2}\right)$ sebesar 0,265 yang diartikan bahwa transparansi berpengaruh positif terhadap kinerja anggaran, yang artinya bahwa dengan adanya kenaikan transparansi maka akan dibarengi dengan peningkatan kinerja anggaran sebesar $0,265 \%$.

4. Koefisien regresi $\left(b_{3}\right)$ sebesar 0,420 yang diartikan bahwa partisipasi penyusunan anggaran berpengaruh positif dan signifikan terhadap kinerja anggaran, dimana semakin tinggi partisipasi penyusunan anggaran maka kinerja anggaran akan semakin meningkat sebesar $0,420 \%$.

Pengujian hipotesis dalam penelitian ini dapat diklasifikasikan atas dua pengujian, yakni uji parsial (uji t) dan uji simultan (uji f).

a. Uji Parsial (Uji t)

Uji parsial digunakan untuk menguji pengaruh akuntabilitas, transparansi dan partisipasi penyusunan anggaran dalam kaitannya dengan kinerja anggaran pada Kantor Pemerintah Kabupaten Luwu Timur. Pengujian parsial dapat dilakukan dengan membandingkan antara nilai signifikan dengan nilai standar. Apabila nilai sign. lebih besar dari nilai standar berarti memberikan pengaruh yang signifikan.

Berdasarkan tabel 4.1 maka diketahui bahwa variabel akuntabilitas memiliki nilai sig $=0,040$, transparansi memiliki nilai sig $=0,000$, dan partisipasi penyusunan anggaran dengan nilai sig $=$ 0,000 , karena nilai sig. dari ketiga variabel bebas lebih kecil dari nilai standar $(0,05)$, berarti dapat dikatakan bahwa ketiga variabel yakni akuntabilitas, transparansi dan partisipasi penyusunan anggaran mempunyai pengaruh signifikan terhadap kinerja anggaran pada Pemerintah Daerah Kabupaten Luwu Timur.

b. Uji Serempak (uji F)

Uji serempak digunakan untuk menguji apakah akuntabilitas, transparansi dan partisipasi penyusunan anggaran mempunyai pengaruh secara serempak atau bersama-sama terhadap kinerja anggaran pada Kantor Pemerintah Daerah Kabupaten Luwu Timur. Pengujian serempak (uji F) dapat dilakukan dengan membandingkan antara nilai sign. dengan nilai standar. Apabila nilai sign. lebih kecil dari nilai standar, berarti memberikan pengaruh secara serempak atau bersama-sama. Hasil pengujian secara serempak dapat dilihat pada tabel berikut ini:

Tabel 2 Hasil Pengujian secara Serempak

\begin{tabular}{lccccc}
\hline \multicolumn{1}{c}{ Model } & $\begin{array}{c}\text { Sum of } \\
\text { Squares }\end{array}$ & Df & $\begin{array}{c}\text { Mean } \\
\text { Square }\end{array}$ & F & Sig. \\
\hline Regression & 10.064 & 3 & 3.355 & 36.994 & $.000^{\mathrm{b}}$ \\
\hline Residual & 9.793 & 108 & .091 & & \\
\hline Total & 19.857 & 111 & & & \\
\hline
\end{tabular}

Berdasarkan hasil pengujian serempak, maka diperoleh nilai signifikan $=0,000$, karena nilai signifikan $0,000<0,05$ (nilai yang sudah distandarkan), maka dapat dikatakan bahwa akuntabilitas, transparansi dan partisipasi penyusunan anggaran mempunyai pengaruh secara serempak atau bersama-sama terhadap kinerja anggaran pada Kantor Pemerintah Daerah Kabupaten Luwu Timur.

Pengaruh akuntabilitas terhadap kinerja anggaran pada Kantor Pemerintah Daerah di Kabupaten Luwu Timur

Hasil persamaan regresi maka diperoleh nilai koefisien regresi sebesar 0,181 , yang berarti bahwa akuntabilitas mempunyai pengaruh positif terhadap kinerja anggaran, selain itu memiliki nilai sign. 0,040 < 0,05 , sehingga dapat dikatakan bahwa akuntabilitas berpengaruh signifikan terhadap kinerja anggaran pada Kantor Pemerintah Daerah di Kabupaten Luwu Timur. Menurut Anggarini dan Puranto (2010) bahwa akuntabilitas mengacu pada adanya kewajiban bagi pihak pemegang amanah (agent) untuk memberikan pertanggungjawaban, menyajikan, melaporkan dan mengungkapkan segala aktivitas dan kegiatan yang menjadi tanggungjawab-nya kepada pihak pemberi amanah yang menilai hasil dan kewenangan untuk meminta pertanggungjawaban tersebut.

Hasil temuan secara emprik di lapangan menemukan bahwa akuntabilitas sudah tinggi atau baik, hal ini dapat dilihat bahwa rata-rata instansi Pemerintah Daerah Kabupaten Luwu Timur sudah menerapkan SOP dalam pelayanan publik, Penyelenggaraan urusan pemerintahan sudah sesuai dengan visi dan misi dimana setiap pegawai diberikan tugas dan tanggungjawab dalam melakukan pekerjaan, Pimpinan atau atasan secara langsung selalu rutin melakukan pemantauan atau monitoring atas proses dan laporan pertanggungjawaban sehingga dapat meningkatkan kinerja pegawai, Pengawasan anggaran sudah dilakukan dengan baik, kemudian laporan pertanggungjawaban anggaran selalu disajikan secara tepat waktu serta adanya pengawasan proses dan laporan pertanggungjawaban Pemerintah Daerah, sehingga dengan baiknya akuntabilitas perusahaan maka akan meningkatkan kinerja anggaran. Penelitian ini sejalan dengan penelitian yang dilakukan oleh Setyaningrum (2017) yang menemukan bahwa akuntabilitas berpengaruh positif dan signifikan terhadap kinerja anggaran, sedangkan Adiwirya dan Sudana (2015) bahwa 
akuntabilitas berpengaruh positif dan signifikan terhadap kinerja anggaran.

Pengaruh transparansi terhadap kinerja anggaran pada Kantor Pemerintah Daerah di Kabupaten Luwu Timur

Hasil analisis koefisien regresi maka diperoleh hasil koefisien regresi untuk transparansi sebesar 0,265 yang berarti bahwa transparansi berpengaruh positif terhadap kinerja anggaran pada Kantor Pemerintah Daerah di Kabupaten Luwu Timur. Selain itu memiliki nilai sign. $0,000<0,05$, hal ini berarti bahwa transparansi berpengaruh signifikan terhadap kinerja anggaran pada Kantor Pemerintah Daerah di Kabupaten Luwu Timur. Menurut Mardiasmo (2010) bahwa transparansi berarti keterbukaan openness pemerintah dalam memberikan informasi yang terkait dengan aktivitas pengelolaan sumber daya publik kepada pihak-pihak yang membutuhkan informasi. Ini berarti bahwa kebijakan dalam penyusunan anggaran yang dibuat oleh pemerintah merupakan variabel yang penting dalam menentukan keberhasilan pelaksanaan anggaran, oleh karena itu semakin transparan kebijakan itu sendiri maka akses informasi dapat dengan mudah diketahui oleh publik.

Hasil pengamatan di lapangan maka diperoleh temuan empirik bahwa penyusunan anggaran oleh Pemerintah Daerah harus dilakukan secara tepat, jelas dan terbuka, kemudian masyarakat selalu mengharapkan pengungkapan kepada publik mengenai aktivitas dan kinerja yang dicapai oleh Pemerintah Daerah, serta penyajian informasi keuangan dalam penyusunan anggaran kepada publik sudah dilakukan secara transparan, sehingga dengan adanya transparansi yang dilakukan oleh kantor pemerintah daerah kabupaten Luwu Timur terhadap anggaran yang dilakukan maka dapat mempengaruhi peningkatan kinerja anggaran yang bermanfaat terhadap masyarakat atau publik. Penelitian ini sejalan dengan penelitian yang dilakukan oleh Setiyaningrum (2017) menemukan bahwa transparansi berpengaruh positif dan signifikan terhadap kinerja anggaran. Kemudian Adiwirya dan Sudana (2015) bahwa transparansi berpengaruh positif pada anggaran berbasis kinerja.

Pengaruh partisipasi penyusunan anggaran terhadap kinerja Anggaran pada Kantor Pemerintah Daerah di Kabupaten Luwu Timur

Hasil analisis persamaan regresi maka diperoleh koefisien regresi sebeasr 0,420 , selain itu memiliki nilai sign. $0,000<0,05$, hal ini berarti dapat disimpulkan bahwa partisipasi penyusunan anggaran mempunyai pengaruh positif dan signifikan terhadap kinerja anggaran pada Kantor Pemerintah Daerah di Kabupaten Luwu Timur. Menurut Bagus (2010) mengemukakan bahwa partisipasi penyusunan anggaran adalah proses pengambilan keputusan bersama oleh dua bagian atau lebih pihak dimana keputusan tersebut akan memiliki dampak masa depan terhadap mereka yang membuatnya. Hasil penelitian yang dilakukan diperoleh temuan empirik di lapangan bahwa pimpinan instansi harus memiliki alasan yang jelas saat melakukan revisi anggaran yang telah ditetapkan selama ini, kemudian setiap pimpinan Instansi pemerintah dituntut melibatkan pegawai dalam penyusunan anggaran tanpa ada diskriminatif sehingga pegawai termotivasi dalam penyusunan anggaran. Kemudian untuk menghasilkan anggaran berbasis kinerja, maka perlu ditunjang oleh adanya kontribusi atau peran dari setiap pegawai dalam penyusunan anggaran, begitu pula bahwa setiap pegawai diharapkan dapat menyampaikan pendapat atau gagasan dalam penyusunan anggaran, serta perlu frekuensi pemberian saran dan pendapat dalam penyusunan anggaran. Penelitian ini sejalan dengan penelitian yang dilakukan Wibowo (2017) yang menunjukkan bahwa partisipasi penyusunan anggaran berpengaruh positif dan signifikan terhadap kinerja.

\section{SIMPULAN}

Hasil penelitian menyimpulkan bahwa peningkatan akuntabilitas yang diikuti transfaransi serta adanya partisipasi penyusunan anggaran dapat meningkatkan kinerja anggaran pada Kantor Pemerintah Daerah Kabupaten Luwu Timur. Faktor partisipasi penyusunan anggaran merupakan unsur dominan dalam peningkatan kinerja anggaran pada Kantor Pemerintah Daerah Kabupaten Luwu Timur

\section{DAFTAR PUSTAKA}

Abdul Hafiz Tanjung. 2014. Akuntansi, Transparansi, dan Akuntabilitas Keuangan Publik. Penerbit: BPFE UGM.Yogyakarta

Adiwirya, M. F., \& Sudana, I. P. (2015). Akuntabilitas, Transparansi, dan Anggaran Berbasis Kinerja pada Satuan Kerja Perangkat Daerah Kota Denpasar. Jurnal Akuntansi, 11 No. 2

Anwar, M. S dan Sumiati. 2014. Pengaruh Partisipasi Penyusunan Anggaran Terhadap Kinerja Aparat Daerah. Jurnal Manajemen. Vol. 1 No. 2

Arifani, R. (2018). Pengaruh Good Corporate Governance Terhadap Kinerja Keuangan Perusahaan. Malang: Universitas Brawijaya.

Arikunto, Suharsimi. (2012). Prosedur Penelitian Suatu Pendekatan Praktek. Jakarta: Rineka Cipta

Ashari Benni (2013) Pengaruh Partisipasi Penyusunan Anggaran Terhadap Kinerja Manajerial Dengan Budaya Organisasi dan Struktur Organisasi Sebagai Variabel Moderating (Studi Empiris pada SKPD di Kabupaten Agam). Artikel Ilmiah. Universitas Negeri Padang

Bagus, Dharmanegara Ida Agung. 2010. Penganggaran Perusahaan Teori dan Aplikasi. Penerbit: Graha Ilmu. Yogyakarta

Brownell, P. dan M. McInnes. 1986. Budgetary Participation, Motivation, and Managerial Performance.The Acccounting Review. Vol. LXI(4). October: 587-600.

Ghozali, Imam. 2016. Aplikasi Analisis Multivariete Dengan Program IBM SPSS 23 (Edisi 8). Cetakan 
ke VIII. Semarang: Badan Penerbit: Universitas Diponegoro.

Halim, H., Lewangka, O., \& Menne, F. (2019). Pengaruh Akuntabilitas, Transparansi Dan Partisipasi Penyusunan Anggaran Terhadap Kinerja Keuangan Pemerintah Kabupaten Enrekang. Indonesian Journal of Business and Management, 1(2), 25-31.

Lestari Dwi Handayani (2011) Partisipasi Penyusunan Anggaran Terhadap Kinerja Anggaran di Kabupaten Semarang. Jejak, Volume 4, Nomor 1, Maret 2011

M Nafarin, 2012, "Penganggaran Perusahaan", Penerbit: Salemba empat, Jakarta.

Mahmudi. 2016. Analisis Lapoan Keuangan Pemerintah Daerah Edisi Ketiga, Penerbit: UPP STIM YKPN. Yogyakarta

Mardiasmo. 2010.Akuntansi Sektor Publik. Penerbit: Andi Yogyakarta

Moeheriono. 2012. "Pengukuran Kinerja Berbasis Kompetensi”. Penerbit: Raja Grafindo Persada, Jakarta

Purnomo, Budi S, and Cahaya Putri. 2018. "Berkonsep Value for Money." 6(3): 467-76.

Setyaningrum. 2017. Pengaruh Akuntabilitas, Transparansi, dan Pengawasan terhadap Kinerja Anggaran Berbasis Value for money pada Badan Usaha Milik Daerah (BUMD). Jogjakarta Jurnal Jurusan Akuntansi Universitas Negeri Yogjakarta

Sugiyono.2016. Metode Penelitian Kuantitatif Kualitatif dan Kombinasi (Mixed Methods). Penerbit : Alfabeta, Bandung.

Suliyanto. 2018. Metode Penelitian Bisnis. Penerbit : Andi Offset, Yogyakarta.

UU No.14 Tahun 2008 Tentang Keterbukaan informasi publik

UU. No 23 Tahun 2014 Tentang Pemerintah Daerah

Wibowo. (2017). Manajemen Kinerja. Edisi Kelima. Depok: PT. Raja Grafindo Persada. 